Received on (01-09-2019) Accepted on (02-03-2020)

\section{Factors Affecting Reading Comprehension Skill of Secondary School Students at \\ Marka Directorate of Education in Jordan from the Perspective of Teachers}

Main Researcher :

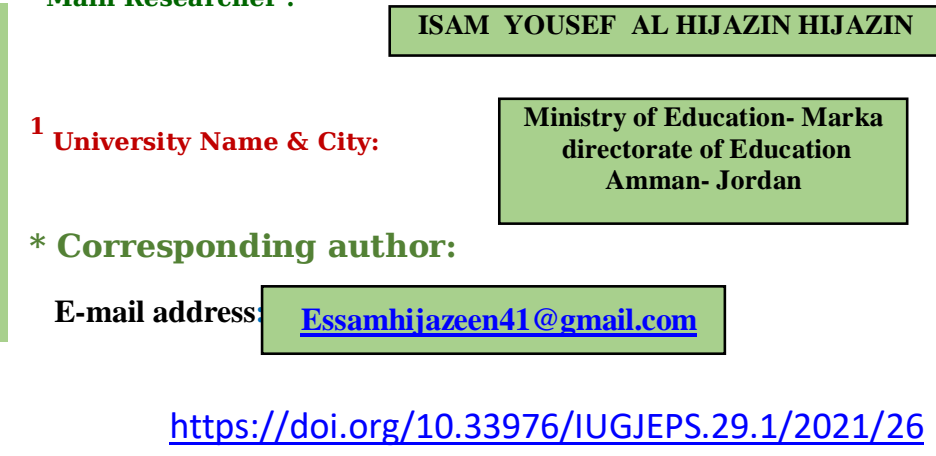

Factors Affecting Reading Comprehension Skill of Secondary School Students at Marka Directorate of Education in Jordan from the Perspective of Teachers

\title{
Abstract:
}

Reading comprehension is one of the four skills of language. This research paper aims to investigate factors that influence the skill of reading comprehension of secondary school students at Abdel Malik Ibn Marwan, Marka, Amman, Jordan. The sample comprised (77) teachers (35) male and (42) female teachers which forms about $(8 \%)$ of the total number of the study population. The findings revealed that the factor that was highly influential and led to students' weakness in reading pertains to the students themselves with a mean of (4.24) and a standard deviation of (0.32). The domain of teachers rated second with a mean of (3.60) and (0.06) deviation. The domain of the textbooks rated third with a mean (3.50) and (1.08) deviation. The findings also revealed that there were no differences with statistical significance at the level of $\leq 0.05) \alpha$ ( which might be attributed to the following variables: gender, qualification and teachers' experience. There were also no differences attributed to the interaction between the variables of students' weakness pertaining to the skill of reading comprehension.

Keywords: Reading comprehension. Domain. Textbook. Gender. Qualification.

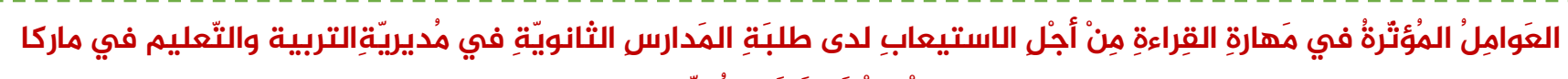

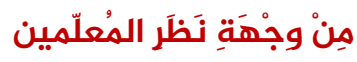

الملخص:

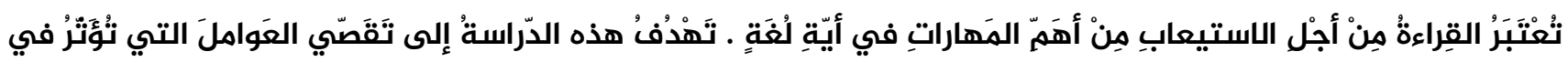

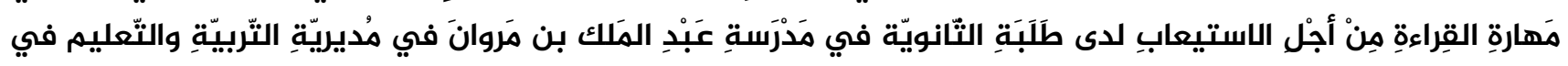

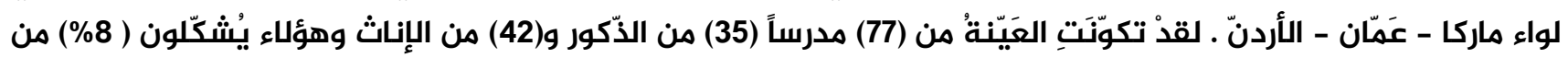

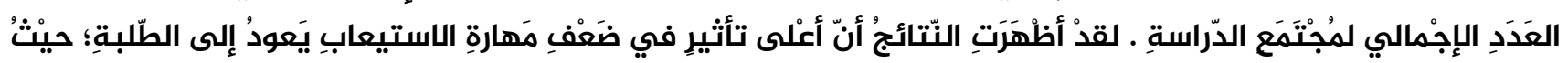

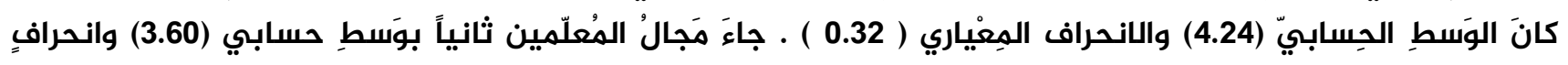

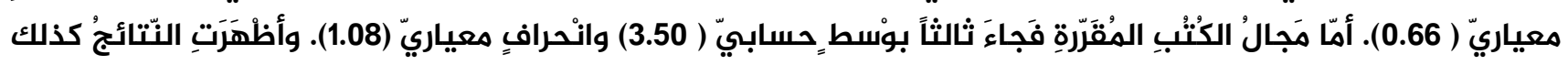

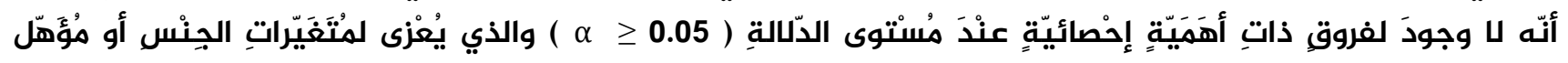

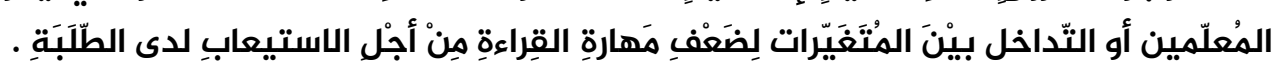


Linguists define language as a system of sounds, words, and symbols by which people communicate ideas and thoughts. Every people has his own language which all members use for communication. This type is known as the mother tongue (L1). As for the fast technological development in the world, individuals felt it necessary to learn a second language to facilitate communication with others in this world.

English language is spoken throughout the whole world from Europe to Asia, to Africa etc.

In some countries it is used as a second language, while in others it is used as a foreign language. In the last two cases, English is considered to be (L2). Mitchell \& Myles (2004) pointed out that learning a second language is not an easy job for learners due to the differences between (L1) and (L2). Thus, acquiring the skills of (L2) including the skill of reading comprehension is a burden for such learners who need to transform the written text into ideas and thoughts of their own (Ruddel, 2002).

Learning the skill of reading is not an easy task to perform. Because of that, linguists worked hard to come up with certain teaching methods to make it easy for foreigners to learn a foreign language.In the case of this study, it is English. Due to that, a number of different methods of teaching English were devised such as: grammar translation method, direct method, oral aural method, eclectic method, etc. Most linguists concerned with problems of reading skills focused on two of its major components: fluency, and accuracy. Logan (1977) and Rasinsiki, Samuels, Herbert, Petscher, \& Feller (2011) considered fluency to be the major component of effective reading. This skill develops through the learner's acquisition of vocabulary, stress, pauses, body language, etc.

As for Pikulski \& Chard (2005), they described fluency to be a means by which the reader through word recognition could comprehend the text. Thus, word recognition plays a role in fluency. Schtsheider \& Torgesen (2004) pointed out that fluency has two constituents speed and accuracy which are prior to student's being fluent in reading comprehension. Hasbrouck (1998) listed five activities necessary for successful reading: focusing on letters of the word, not on pictures and every single letter, make use of letter sound to identify words, be able to decode words through using a strategy the reader is familiar with, and repeat reading words till they become automatic for the reader.

Reading comprehension could be difficult. Prado \& Polurde (2005) mentioned that the correlation between word and cognitive abilities is not easy. Hence, poor reading comprehension might be traced back to lack of experience, cognitive ability, and physical disabilities. In addition to the aforementioned factors, the strategy the teacher adopts in the process of teaching plays a role in a successful teaching of reading comprehension.

This study is important because it is the product of a long experience of teaching English for the researcher himself has been a teacher of English who has been teaching the language for many years. It is worth mentioning that in Jordan most teachers use the grammar translation method and the oral aural method to a lesser degree. As the researcher himself is a teacher who has applied these two teaching methods, the results of the study can be representative of the study population.

\subsection{Aims of the Study:}


The study aims to investigate the factors that influence the skill of reading comprehension of students at secondary schools as exemplified in the viewpoint of teachers at Abdel Al-Malek Bin Marwan Secondary School, Marka directorate of Education. It is hoped that the results and recommendations will benefit students and teachers in this directorate and in Jordan in general.

\subsection{Problem of the Study:}

The study is concerned with the problem of reading comprehension for secondary students at Abdel Al-Malek Bin Marwan from the perspective of teachers. Such a problem is presented through posing the following two questions:

1- What are the factors that affect the comprehension skill of students of the aforementioned school?

2- Are there any differences with statistical significance which might be attributed to any of the following variables: experience, gender, qualification, or interaction between variables?

\subsection{Significance of the Study:}

The study's significance stems from the long experience which the researcher has in the field of teaching English. To his knowledge, not much was written on the subject of factors influencing reading comprehension. This is another reason that motivated him to write on the issue hoping that the findings will be of great benefit for students, teachers of English and curricula planners.

\subsection{Limitations of the Study:}

With regard to space, the study is limited to teachers of English at Abdel Al-Malek Bin Marwan Secondary School at Marka, Amman, Jordan. Regarding time limit, the study was conducted in the first semester 2018/2019.

\section{Literature Review:}

The following are summaries of studies relevant to this one. The first is that of Lee (2011) who adopted the theories of Bakhtin who emphasized two points in those theories: individual differences which distinguish one reader from another depending on how each of them interprets the text according to his understanding. In his study, he compared how two different Chinese came up with different meanings of the same article they both read. He concluded that teachers of L2 should involve in dialogue pedagogy which can be used as a criterion for evaluating meaning constructed by the reader of the text.

Lesaux, et.al, (2011) conducted a study on 87 students who were native speakers of Spanish in southwestern U.S schools so as to find out whether or not Spanish affects reading comprehension of such students. They found out that oral language skills significantly affected L2 reading comprehension.

Ercitin, (2010) conducted a study on students from Turkish universities to find out if prior knowledge and interest in the topic influenced the performance of such students in reading comprehension. The findings revealed that interest in the topic had a great influence on students, while fore knowledge didn't have any significance.

Netten (2011) conducted a study on a randomly-selected group of students (729) from the Netherlands learning first language (L1) and another group comprising (93) L2 learners. The results showed that home readings and practice did make a difference thus, prior readings for sure help in facilitating reading comprehension. 
Al-Jamal, Al-Hawamleh, and Al-Jamal (2013) conducted a study to measure the reading comprehension proficiency of Jordanian students. The study focused on identifying the main idea of a paragraph. Moreover, it examined comprehension instruction that teachers give to students. (649) 10th grader students from Irbid directorate in the scholastic year (2011/2012) took a reading comprehension test. (15) teachers were also observed. The findings revealed that students had a moderate reading comprehension proficiency and that they neglected teachers' instructions. Thus, the study recommended that teachers need to instruct comprehension strategies that help students approach reading passages.

Freahat and Faoury's study (2014) examined the students and teachers' "attitudes towards the appropriateness and the difficulty level of the reading content in secondary stage EFL textbooks in Jordan and an introductory EFL textbook taught in the Jordanian universities" (p. 2231). University instructors, secondary teachers, high school students, and freshmen university students participated in the study. The questionnaire results showed that the students their English books suitable, which prepared them for the university reading level. By contrast, the teachers and instructors considered the reading content in these three textbooks easy though still difficult for the students as most first year university students were generally unprepared for the reading demand they have to meet at the university.

Wu, Valcke and Keer (2018: 34) pinpoint that "student's individual, family, and teacher factors play a significant role in children's reading development". Their study was directed to develop a multilevel comprehensive model that takes all these factors into account. The researchers studied reading comprehension of 1322 Chinese secondary school students from five secondary schools. "The student-level variables included student's gender, autonomous reading motivation, controlled reading motivation, metacognitive awareness of reading strategies (MARS), and household income" (ibid). on the other hand, the class-level variables were the teacher's qualification as well as his/her experience. It was found that the most robust correlates of reading comprehension were the student's MARS and autonomous reading motivation. Moreover, teacher's qualification and experience facilitated the correlate between MARS and reading comprehension.

Haq, Khurram and Bangash (2019:85) state that "active learning and teaching methodologies can make a positive difference in students learning especially for second language learners". The study investigated the effect of using activity-based learning method on the development of reading skills of 50 sixth graders selected from Iqbal High School Tarkha. The participants were equally divided into experimental and control groups. "While the experimental group was taught using activity based learning method, the control group received routine teaching instructions" (ibid). The study found that the experimental group had better results in reading than control group in the post-test. Thus, the researchers recommended that teachers need to get students involved in reading by introducing meaningful and challenging activities.

Alluhaydan (2019) studied the online metacognitive reading strategies Saudi male and female learners used more frequently in Arabic and English. It was found that the lack of practicing reading in either language affected their comprehension skills. However, there were no differences that can be attributed to gender in terms of the use of global, and problem-solving metacognitive online 
reading strategies. Nonetheless, male participants said that they use global and problem-solving strategies more often than their female counterparts.

Nevo and Vaknin-Nusbaum (2020) focused on motivation of Hebrew first-grade students. The results indicate that reading achievement of the intervention group was improved in comparison with the control group. The study emphasized the importance of reading instruction in promoting reading motivation.

Gao, Zhao, Li, Mao, Chen, and Harrison (2020:42) "compared the effects of a three-week intervention undertaken in China on reading speed and reading achievement between primary school students in experimental and control groups". The study found that students in the intervention group were significantly better in reading speed than their control group counterparts. The study also found that instruction has positive effect on reading fluency and comprehension.

Hassanabadi et al. (2018) studied reading comprehension in three groups that differed in their reading abilities. It was found that reading comprehension performances were not so different among the three groups and there were no sex differences either.

Alzboun (2020) investigated the inclusion of the reading strategies in Action Pack 6. The study shed light on the role of textbooks in developing student's abilities to use various learning strategies. Reading activities were classified according to the nine reading strategies in Brown's classification (2001). Scanning was found to be the mostly used strategy (57\%). Additionally, it was found that Action Pack did not provide students with appropriate and balanced reading activities to help them use the reading strategies especially the ones that need higher thinking processes.

To sum up, there are various factors that may affect reading comprehension skills. The abovementioned studies looked at the topic from different angles. Lee's (2011) study found that teachers of L2 should involve in dialogue pedagogy. Lesaux, et.al, (2011 concluded that oral language skills significantly affected L2 reading comprehension. Ercitin's findings (2010) revealed that interest in the topic had a great influence on students. This study emphasizes the role of textbook material on students' comprehension skills. The study of Al-Jamal, Al-Hawamleh, and Al-Jamal (2013) revealed that students had a moderate reading comprehension proficiency and that they neglected teachers' instructions. This, in turn, sheds light on the role that qualifications play in developing reading comprehension skills. Freahat and Faoury's study (2014) focused on the difficulty level of the students' textbooks. They found that teachers consider secondary stage textbooks easy though still difficult for the students. Wu, Valcke and Keer (2018) concentrated on motivation and its relationship with the reading compression skills. They found that teacher's qualification and experience facilitated the correlate between metacognitive awareness of reading strategies and reading comprehension. Haq, Khurram and Bangash (2019) focused on the teacher's role in developing his/her students' reading skills. The researchers recommended that teachers need to get students involved in reading by introducing meaningful and challenging activities. Alluhaydan (2019) did not find any effect of gender on the use of global, and problem-solving metacognitive online reading strategies. By the same token, Hassanabadi et al. (2018) found that there were no sex differences in students' performance on reading comprehension activities. Nevo and VakninNusbaum (2020) emphasized the importance of reading instruction in promoting reading motivation. Gao, Zhao, Li, Mao, Chen, and Harrison (2020) concluded that instruction has positive 
effect on reading fluency and comprehension, hence emphasizing the role of the teacher in developing students' reading skills. Alzboun (2020) was concerned about the content of the textbook and how it affects students' reading comprehension skills. He found that Action Pack did not provide students with appropriate and balanced reading activities to help them use the reading strategies.

\section{Methodology:}

In this study, the survey method used is a questionnaire applied to a sample of English teacher's at the secondary stage in Amman to explore the factors that affect the skill of reading comprehension of English at that level.

\subsection{Study Population:}

The study population comprised teachers of English at the secondary level in the directorate of Marka and Wadi Al-Seir, Amman with a total number of (1032) teachers (512) males and (520) females.

\subsection{Study Sample:}

The sample comprised (77) teachers, (35) males and (42) females which equals (8\%) of the total number of the population, as presented in the following table:

Table (1) Distribution of the Sample by gender, qualification and the experience

\begin{tabular}{|c|c|c|c|}
\hline $\begin{array}{l}\text { Demographic } \\
\text { Variable }\end{array}$ & Variable' Categories & $\mathbf{F}$ & $\%$ \\
\hline \multirow[t]{2}{*}{ Gender } & Male & 35 & 45.5 \\
\hline & Female & 42 & 54.5 \\
\hline \multicolumn{2}{|l|}{ Total } & 77 & 100 \\
\hline \multirow[t]{2}{*}{ Qualification } & Bachelor Degree & 63 & 81.8 \\
\hline & Master Degree & 14 & 18.2 \\
\hline \multicolumn{2}{|l|}{ Total } & 77 & 100 \\
\hline \multirow[t]{3}{*}{ Experience } & $1-5$ years & 21 & 27.3 \\
\hline & $6-10$ years & 31 & 40.3 \\
\hline & 11 and above & 25 & 33.4 \\
\hline \multicolumn{2}{|l|}{ Total } & 77 & 100 \\
\hline
\end{tabular}

\subsection{Study Tool:}

The researcher designed a questionnaire of two parts:

The first included information about the sample members related to gender, qualification, and experience. The second part comprised (30) items to investigate the factors that influence the students' reading comprehension skill at the secondary level in Amman. The items were distributed into three major domains:

- Students' domain: (14) items.

- Teachers' domain: (9) items.

- Textbook domain: (7) items.

Tool items were graded using Likert Scale.

\subsection{Variables and Methodology}


The variables under question are gender, experience, and qualification. Each of these will be taken individually to see if it affects students' reading comprehension skills. Then, the interaction between these variables will be studied as well. The study follows the descriptive approach. Each variable will be calculated using the statistical package program (SPSS), and the variables will be discussed in light of the results.

\subsection{Validity:}

The validity of the study was checked by experienced referees in education. Some modifications were taken into in compliance with expertise suggestions.

The (30) items were considered valid according to $(82 \%)$ of the referees' views that the items were propitious for the study.

\subsection{Reliability:}

To calculate the questionnaire reliability, test-re-test and internal reliability methods were used. The questionnaire was given to (20) male teachers and (25) female teachers to respond to the items. After two weeks, the tool was distributed to the same teachers to respond to the items again. The results are shown in table (2).

Table (2) Reliability Coefficients of the Questionnaire by Test-re-Test and Internal consistency methods

\begin{tabular}{|l|l|l|}
\hline Domain & Test-re-Test & Internal consistency \\
\hline Students & 0.81 & 0.83 \\
Teachers & 0.79 & 0.81 \\
textbooks & 0.76 & 0.79 \\
\hline The tool as a whole & 0.86 & 0.88 \\
\hline
\end{tabular}

\subsection{Statistical Methods:}

In answering question (1), arithmetic mean and standard deviation were used, while in answering question (2), three- way MANOVA was used.

\subsection{Standard of judgment:}

The standard of level of importance was used to measure the factors that affect students' reading comprehension skill of English for secondary students in Abdel Al-Malek Bin Marwan at Marka, Amman

Table (3) Standard of Level of Importance Set for Responses in each Domain or Item

\section{Results and Discussion:}

\begin{tabular}{|l|l|}
\hline Range of values & Level of Importance \\
\hline $1.00-1.8$ & Very Low \\
\hline $1.81-2.60$ & Low \\
\hline $2.61-3.40$ & Medium \\
\hline $3.41-4.20$ & High \\
\hline $4.21-5.00$ & Very High \\
\hline
\end{tabular}


Answers to question one: "Are there factors affecting the students' reading comprehension skills in English Language at the secondary level in Abdel Al- Malek Bin Marwan Secondary school in Amman, Jordan?". The results are presented in the following table:

Table 4: Mean, Standard Deviation, Rank and Importance Level of Students Domain Items $(n=77)$

\begin{tabular}{|l|l|l|l|l|l|}
\hline No. & item & M & S D & Rank & $\begin{array}{l}\text { Importance } \\
\text { Level }\end{array}$ \\
\hline A10 & $\begin{array}{l}\text { Students concentrate on memorizing than } \\
\text { comprehending }\end{array}$ & 4.61 & .49 & 1 & Very High \\
\hline A4 & Students don't understand correct rules of reading & 4.55 & .55 & 2 & Very High \\
\hline A9 & Students' disability in connecting meanings & 4.43 & .64 & 3 & Very High \\
\hline A6 & $\begin{array}{l}\text { Students were unable to guess the meaning of new } \\
\text { vocabulary }\end{array}$ & 4.43 & .64 & 4 & Very High \\
\hline A13 & $\begin{array}{l}\text { Students couldn't estimate the significance of } \\
\text { reading }\end{array}$ & 4.39 & .65 & 5 & Very High \\
\hline A1 & Students' lack of interest in English Language & 4.31 & .52 & 6 & Very High \\
\hline A12 & Students' lack of interest in silent reading & 4.29 & .48 & 7 & Very High \\
\hline A11 & Students couldn't recognize keywords in the text & 4.26 & .66 & 8 & Very High \\
\hline A7 & Students' weakness in spelling words & 4.25 & .65 & 9 & Very High \\
\hline A3 & Students' weakness in words pronunciation & 4.12 & .58 & 10 & High \\
\hline A8 & A student feels confused when he reads & 4.09 & .71 & 11 & High \\
\hline A5 & $\begin{array}{l}\text { Lack of Students' understanding the reading } \\
\text { objectives }\end{array}$ & 3.99 & .90 & 12 & High \\
\hline A14 & Students did use technology as an aid for reading & 3.84 & 1.03 & 13 & High \\
\hline A2 & Students' weakness in eye-movement during reading & 3.78 & 1.00 & 14 & High \\
\hline & average & 4.24 & .32 & & \\
\hline
\end{tabular}

The results revealed that the highest effect on student's weakness in reading comprehension skill was in the students' domain with a mean of (4.24), and standard deviation of (0.32). The means of items of students' domain were (4.61) for item (A10) which runs (Students concentrate on memorizing than comprehending), and the lowest mean was (3.78) for item (A2) which runs (Students' weakness in eye-movement during reading). Some of these items, in fact, indirectly agree with Lesaux, et.al, (2011 study which found that oral language skills affect L2 reading comprehension.

\subsection{Discussion of Question One:}

The preceding findings of this question show that students' weakness in English might be referred back to incompetent teachers who might have taught them in addition to the negative attitude they hold toward the language. Moreover, students mainly focus on grammar at the expense of other skills, reading comprehension in particular.

Regarding the domain of teachers table (5) below presents the details: 
Table 5: Mean, Standard Deviation, Rank and Importance Level of Teachers' Domain Items $(\mathrm{N}=77)$

\begin{tabular}{|l|l|l|l|l|l|}
\hline No. & item & M & S D & Rank & $\begin{array}{l}\text { Importance } \\
\text { Level }\end{array}$ \\
\hline B7 & $\begin{array}{l}\text { Students weren't encouraged by teachers to develop their } \\
\text { fluency and speed in reading }\end{array}$ & 3.88 & 1.08 & 1 & High \\
\hline B1 & Teachers didn't concentrate much on reading skills & 3.71 & .69 & 2 & High \\
\hline B2 & Teachers didn't absorb well methods of teaching & 3.62 & .97 & 3 & High \\
\hline B6 & Teachers neglect the playing technique in reading & 3.61 & 1.26 & 4 & High \\
\hline B5 & Teachers concentrate more on structures than other skills & 3.56 & 1.16 & 5 & High \\
\hline B8 & Teachers' weakness in class communication skills & 3.48 & 1.30 & 6 & High \\
\hline B4 & $\begin{array}{l}\text { Teachers didn't encourage student to memorize what they } \\
\text { read }\end{array}$ & 3.47 & 1.20 & 7 & High \\
\hline B9 & Standard of reading texts was poor & 3.42 & 1.38 & 8 & High \\
\hline B3 & Teachers didn't encourage students to read on their own & 3.38 & 1.14 & 9 & Medium \\
\hline & average & 3.60 & .66 & & \\
\hline
\end{tabular}

The domain of teachers rated second with a mean (3.60) and the deviation (0.66).

The means of the items of this domain came between (3.88) for item (B7) which runs (Lack of teachers' encouragement for students to develop their fluency and speed in reading), and the lowest mean was (3.38) for item (B3) which is (Lack of teachers' encouragement for students in selfreading). The findings of this study agree with the results of some studies mentioned above.

Here in this domain, the results agree with those of Lee (2011) who found that lack of teacher's encouragement affects students' comprehension skill. Item B9 agrees with Al-Jamal, Al-Hawamleh, and Al-Jamal (2013) who revealed that students had a moderate reading comprehension proficiency. Items B3, B4, B7 also agree with $\mathrm{Wu}$, Valcke and Keer (2018) that motivation is important in developing students' reading compression skills. They found that teacher's qualification and experience facilitated the correlate between metacognitive awareness of reading strategies and reading comprehension. The study also agrees with Haq, Khurram and Bangash (2019) who emphasized the teacher's role in developing his/her students' reading skills. Similarly, the findings here are consistent with Nevo and Vaknin-Nusbaum (2020) who emphasized the importance of reading instruction in promoting reading motivation. B7is also congruent with Gao, Zhao, Li, Mao, Chen, and Harrison (2020) who concluded that instruction has positive effect on reading fluency and comprehension.

As for the domain of textbooks, table (6) below elucidates the results:

Table 6: Mean, Standard Deviation, Rank and Importance Level of Textbooks Domain Items $(\mathrm{N}=77)$

\begin{tabular}{|l|ll|l|l|l|l|}
\hline No. & item & M & S D & Rank & $\begin{array}{l}\text { Importance } \\
\text { Level }\end{array}$ \\
\hline C4 & Different class environments were not cared for in & 3.78 & 1.14 & 1 & High \\
\hline
\end{tabular}




\begin{tabular}{|l|l|l|l|l|l|}
\hline textbooks & & & & \\
\hline C6 & $\begin{array}{l}\text { No teaching aids were used to help students understand } \\
\text { the text or the context }\end{array}$ & 3.74 & 1.19 & 2 & High \\
\hline C5 & $\begin{array}{l}\text { Teachers' book include certain strategies for teaching } \\
\text { reading }\end{array}$ & 3.55 & 1.24 & 3 & High \\
\hline C2 & Textbook material doesn't suit students' attitudes & 3.51 & 1.24 & 4 & High \\
\hline C3 & $\begin{array}{l}\text { Textbook material doesn't suit the cognitive ability of } \\
\text { students }\end{array}$ & 3.45 & 1.18 & 5 & High \\
\hline C1 & $\begin{array}{l}\text { Reading ability was not so good to go along with the text } \\
\text { material }\end{array}$ & 3.42 & 1.28 & 6 & High \\
\hline C7 & Weekly classes for English Language are insufficient & 3.01 & 1.28 & 7 & Medium \\
\hline & average & 3.50 & 1.08 & & \\
\hline
\end{tabular}

The domain of textbooks rated: third with a mean (3.50) and standard (1.08). The most influential factor in students' weakness in reading was item (C4) (Books do not take into consideration different environments), with a mean (3.78). The lowest mean was for item (C7), (weekly classes of English were not enough), with a mean (3.01). The results are presented in table (6). The results agree with Alzboun (2020) that the content of the textbook affects students' reading comprehension skills. They are also congruent with Ercitin's findings (2010) which state that the topic of the reading comprehension had a great influence on students and that the textbook highly affect students reading achievement. It also agrees with Freahat and Faoury's study (2014) that the level of difficulty has a great impact on students' reading skills. Finally, the study agrees with Haq, Khurram and Bangash (2019) who concluded that teachers need to get students involved in reading by introducing meaningful and challenging activities.

In general, the mean of the three domains together was (3.76) and standard deviation was (0.51) as shown in table (7):

Table (7) Mean and standard deviation average of the three domains and the total score

\begin{tabular}{|l|l|l|l|l|l|l|}
\hline No. & Domain & N of Items & M & S D & Rank & Importance Level \\
\hline A & Students & 14 & 4.24 & .32 & 1 & Very High \\
\hline B & Teachers & 9 & 3.60 & .66 & 2 & High \\
\hline C & Textbooks & 7 & 3.50 & 1.08 & 3 & High \\
\hline \multicolumn{2}{l}{ Total score } & 30 & 3.76 & .51 & & \\
\hline
\end{tabular}

Results of question two: "Are there any statistically significant differences attributed to the variables of gender, qualification, experience, and interaction between the variables?", table (8) through using (MANOVA) illustrates the whole issue.

Table (8) (MANOVA) for the effect of gender, experience, and qualification in students' weakness in reading comprehension skill and the interaction between them

\begin{tabular}{|l|l|l|l|l|l|l|}
\hline Source & $\begin{array}{l}\text { Dependent } \\
\text { Variable }\end{array}$ & $\begin{array}{l}\text { Type III Sum } \\
\text { of Squares }\end{array}$ & d f & $\begin{array}{l}\text { Mean } \\
\text { Square }\end{array}$ & F & Sig. \\
\hline
\end{tabular}




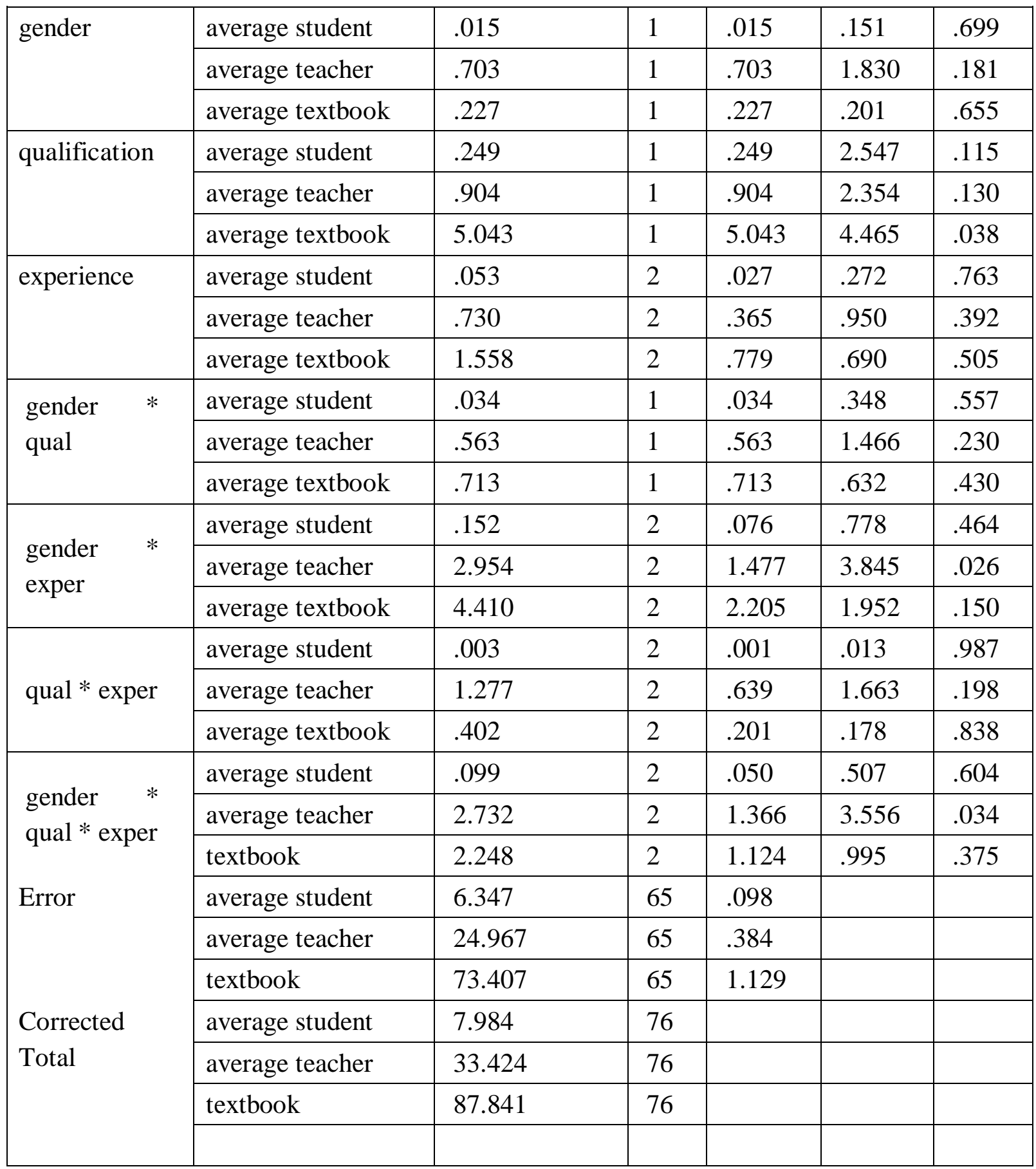

By using (MANOVA) for answering this question, the results indicated that there are no statistically significant differences at the level $(\alpha \geq 0.05)$ attributed to the variables of gender, qualification, and the experience of teachers or interaction between the variables in the weakness of students in reading comprehension skill as table (6) above shows.

\subsection{Discussion of Question Two:}

As perceived from the point of view of teachers, revealed that there were no differences with statistical significance which might be attributed to gender, teachers' experience and their 
qualification regarding weakness of students skill in reading comprehension. This kind of thing might be viewed as a common ground among all teachers teaching English as they faced the same problem of students' weakness in the skill of reading.

In fact, our study first agrees with Alluhaydan (2019) and Hassanabadi et al. (2018) who did not find any effect of gender on students' performance on reading comprehension activities. However, it differs from Al-Jamal, Al-Hawamleh, and Al-Jamal (2013) who indirectly referred part of the students' weakness in reading comprehension skills to neglecting the teachers' instructions. The study also disagrees with Wu, Valcke and Keer (2018) who found that teacher's qualification and experience do facilitate the correlate between metacognitive awareness of reading strategies and reading comprehension. To a certain extent, it, further, disagrees with Gao, Zhao, Li, Mao, Chen, and Harrison (2020) who emphasized the role of the teacher in developing students' reading skills.

It is worth mentioning that though this study is different from the previous studies, it complements them as it looks at the factors that affect reading comprehension skills from a different angle. On one hand, some studies were concerned with motivation, the effect of oral language skills on reading skills, neglecting teachers' instruction, the difficulty level of the students' textbooks, the need to get students involved in reading by introducing meaningful and challenging activities, the importance of reading instruction in promoting reading motivation, and instruction's positive effect on reading fluency and comprehension. On the other hand, our study focused on the impact of gender, experience and qualification on students' achievement in reading comprehension. It also addressed the role that teachers and textbooks play in developing reading skills.

\section{Conclusion:}

Based on the results above, we concluded that:

1. Factors related to students are the most affective ones behind students' weakness in reading comprehension in English as a second language, followed by teachers' factors, then the textbook factor.

2. There are no statistically significant differences attributed to the variables of gender, teachers' experience, and their qualification in their opinions about the weakness of students in the skill of reading comprehension in English.

\section{Recommendations:}

The researcher recommends that:

- Teachers need to attend intensive courses on methods of teaching English.

- Highly competent teachers should be the only ones to be authorized to teach English at early stages of learning this language.

- Training students in English should also focus on all four skills, but not on one skill at the expense of others.

- Teachers need to encourage students to practice more readings through an extra-curricular activity like reading easy short stories at home in order to summarize them in class.

- The textbooks used should include some topics the students are familiar with as that motivate them to read more developing their reading capabilities. 


\section{References}

Al-Jamal, D., Al-Hawamleh, M., \& Al-Jamal, G. (2013). An assessment of reading comprehension practice in Jordan. Jordan Journal of Educational Sciences, 9(3), 335-344.

Alluhaydan, H. (2019). Saudi ESL/EFL Learners' Metacognitive Online Reading Strategies in Arabic and English (Doctoral dissertation, The University of Memphis).

Alzboun, B. K. A. (2020). The Inclusion of Reading Strategies in Action Pack 6 Textbook. Academic Journal of Research and Scientific Publishing| Vol, 1(9).

Cho,S.,Xu,Y., \& Rhodes, J.A.(2010). Examining English language learners' motivation of, and engagement in reading: A qualitative study. The Reading Matrix, 10 2), 205-221.

Ercetin, G. (2010). Effects of topic interest and prior knowledge on text recall and annotation use in reading. ReCall, 22(2), 228-246.

Freahat, N. M., \& Al-Faoury, O. H. (2014). Jordanian High School EFL Teachers' and University EFL Instructors' Perceptions of the Reading Comprehension Content in EFL Textbooks. Theory \& Practice in Language Studies, 4(11).

Gao, T., Zhao, J., Li, X., Mao, Y., Chen, Q., \& Harrison, S. E. (2020). Impact of rapid reading skills training on reading rate and reading achievement among primary school students in China. Educational Psychology, 40(1), 42-61. doi:10.1080/01443410.2019.1607257

Haq, Z. U., Khurram, B. A., \& Bangash, A. K. (2019). Development of Reading Skill through Activity Based Learning at Grade-VI in Khyber Pakhtunkhwa. Bulletin of Education and Research, 41(1), 85-104.

Hasbrouck, J. (1998). Reading Fluency. Principles for instruction and progress monitoring. Professional Development Guide. Austin, TX: Texas Center for reading and Language arts , University of Texas at Austin.

Hassanabadi, H., Talaei, E., Seyed, M. J. A., Bararpour, G., \& Baneshi, A. (2018). Empirical Evidence for Text and Reader Interaction in Fourth Grade Accelerated Students: Is Reading Literacy a Criterion for Academic Acceleration?.

Jitendra, A., \& Gajiria, M. (2011). Reading comprehension instruction for students with learning disabilities. Focus on Exceptional children. 43(8), 1 - 13.

Lee, Y.L. (2010). The application of Bakhtinian theories on second language reading comprehension: A qualitative case study. The Reading Matrix, 10(2), 222-242.

Lesaux, N.K., Crsson, A. C., Kieffer, M. J., \& Pierce, M. (2010) Uneven profiles: language minority learner's word reading, vocabulary, and reading comprehension skills. Journal of Applied Developmental psychology, 31,475-483.

Logan, G. D. (1997). Automaticity and reading perspectives: from the instance theory of autoimmunization. Reading and writing Quarterly, 13.123 - 146.

Mitchell, R. and Myles, F. (2004). Second Language Learning Theories, 2nd edition, Oxford University Press Inc., New York.

Mocallum, R., Krohn, K, Skinner, C., Hilton, A., Hopkins, M., Waller, s., \& Polite , F ., (2010 ). Improving reading comprehension of at - risk high school students: the ART of reading program. Psychology in the Schools, 48, 78 - 87. 
Mohd, Z. (2010). Anxiety and academic reading performance among Malay ESL learners. Journal of Pan-Pacific Association of Applied Linguistics, 14(2), 41-58.

Netten, A., Droop, M., \& Verhoeven, L. (2011). Predictors of reading literacy for first and second language learners. Reading and Writing, 24, 413-425.

Nevo, E., \& Vaknin-Nusbaum, V. (2020). Enhancing motivation to read and reading abilities in first grade. Educational Psychology, 40(1), 22-41. doi:10.1080/01443410.2019.1635680

Palmer,B.C., Zhang ,N., Taylor, S.H., \& Leclere , J.T. (2010). Language proficiency, reading and the Chinese- speaking English language learner. Multicultural Education, 17(2), 44-51.

Pikulski, J., chard. D.J. (2005). Fluency: Bridge between decoding and reading comprehension. The Reading Teacher, 58,510 - 521.

Prado, L., \& Plourde, L. (2005). Increasing reading comprehension through explicit teaching of reading Strategies: is there a difference among the genders?

Rasinski, T. V, Samuels, S. J, Hiebert , E., Petscher , y., \& Feller , k . (2011). the relationship between a Silent. Comprehension and achievement in an urban school setting. Reading Phycology, 32, 75- 97.

Reading improvement, $32-43$.

Ridge, A., \& Skinner, c., (2010). Using the TELLS reading procedure to enhance comprehension Levels and rates in Secondary Students. Psychology in the Schools, 48, 46, 58.

Ruddell, R. B. (2002) . Teaching Children to read and write: Becoming an effective literacy teacher. (Third edition). Boston: Allyn \& Bacon.

Schatshneider, C. \& Torgesen. J. K. (2004). Using our Current understanding of dyslexia to support early identification and intervention. Journal of Child Neurology 19, 10, $759-765$.

Snow, Catheren, E., Griffin, Peg, \& Burns, M. (2005). Knowledge to support the Teaching of Reading for the effect of gender, experience, and qualification on students' weakness in reading comprehension skill and the interaction of them. Jossey - Bass (P. 9). (MANOVA). The Modern Language Journal. (95), 26-43.

Wu, L., Valcke, M., \& Van Keer, H. (2019). Factors associated with reading comprehension of secondary school students. Educational Sciences: Theory and Practice, 19(4), 34 - 47. http://dx.doi.org/10.12738/estp.2019.4.003. 